\title{
Selection of vegetable indicators of indaziflam residues in soil
}

\author{
Renan Rodrigues Braga ${ }^{1} \oplus$, Lino Roberto Ferreira ${ }^{1} \oplus$, Matheus Ferreira França Teixeira' ${ }^{1}$, \\ Valdinei Araújo Gonçalves ${ }^{1}$, Francisco Cláudio Lopes Freitas ${ }^{1} \odot$, Leonardo d'Antonino ${ }^{1}(\mathbb{0}$

\footnotetext{
1 Universidade Federal de Viçosa, Viçosa-MG, Brasil. E-mail: renanrodriguesbraga@gmail.com; Iroberto@ufv.br; teixeiramff@gmail.com; valdinei.goncalves@ufv.br; francisco.freitas@ufv.br; leonardo@ufv.br
}

ABSTRACT: Studies on the behavior of herbicides in the soil (sorption, leaching and persistence) can be conducted by using biological and chemical methods. To use the biological method it is necessary to select species that present, in low concentrations of the herbicide, an easily quantified response in a short period of time. In this research the response of nine vegetable species was quantified in an inert substrate with different concentrations of indaziflam. The response of these species to indaziflam was quantified at 21 days after sowing by means of visual evaluation of the poisoning symptom and the accumulation of dry weight of the plants. All evaluated species were sensitive to indaziflam. The most sensitive species was maize, while sorghum, wheat and oat were the most sensitive species. However, the ease of cultivation of sorghum and its rapid growth, coupled with high sensitivity to indaziflam, make this species more suitable as a test plant for this herbicide. It is concluded that sorghum, wheat and oat can be used to detect indaziflam residues in soils.

Key words: Avena sativa; bioassays; herbicide in the soil; Sorghum bicolor, Triticum spp.

\section{Seleção de espécies vegetais indicadoras de resíduos de indaziflam no solo}

RESUMO: Estudos referentes ao comportamento de herbicidas no solo (sorção, lixiviação e persistência) podem ser realizados utilizando métodos biológicos e químicos. Para utilização do método biológico é necessário selecionar espécies que apresentam, em baixas concentrações do herbicida, resposta de fácil quantificação em curto espaço de tempo. Nesta pesquisa foi quantificada a resposta de nove espécies vegetais cultivadas em substrato inerte com diferentes concentrações do indaziflam. A resposta dessas espécies ao indaziflam foi quantificada 21 dias após o semeio, por meio de avaliação visual do sintoma de intoxicação e do acúmulo de matéria seca das plantas. Todas as espécies avaliadas mostraram-se sensíveis ao indaziflam. A espécie menos sensível foi o milho, enquanto sorgo, trigo e aveia foram as mais sensíveis. Todavia, a facilidade de cultivo do sorgo e seu rápido crescimento, aliado a alta sensibilidade ao indaziflam, fazem com que essa espécie seja a mais indicada como planta teste desse herbicida. Conclui-se que plantas de sorgo, trigo e aveia podem ser utilizados para detectar resíduos de indaziflam em solos.

Palavras-chave: Avena sativa; bioensaios; herbicida no solo; Sorghum bicolor; Triticum spp. 


\section{Introduction}

The chemical Indaziflam (N-[(1R,2S)-2,3-dihydro-2,6dimethyl-1H-inden-1-yl]-6-[(1R)-1-fluoroethyl]-1,3,5-triazine2,4-diamine), part of the alkylazine chemical group, inhibits cellulose biosynthesis in sensitive vegetable species (Myers et al., 2009). This herbicide impedes the formation of the cell wall (Brabham et al., 2014), stops the growth of the plants without affecting the synthesis of polysaccharide polymers, indicating that this inhibition probably occurs in the crosslinking stage of the cellulose microfibrils. The inhibition of cell division from the meristem tissue has also been proposed as a secondary mode of action (Griffin, 2005). According to Kaapro \& Hall (2012), the inhibition of the deposition of crystals on the cell wall affects cell formation, division and elongation; however, the fully developed tissues are not affected by it. Therefore, symptoms in sensitive plants are characterized by the emergence absence and, if there is any, root growth is reduced, leading the plant to reduce its shoot growth and to its consequent death (Griffin, 2005).

In Brazil, indaziflam is registered for use in sugarcane, coffee, citrus, pine, eucalyptus, banana, cashew, coconut, palm oil, guava, mango and grape with its pre-emergence application on weeds (Mapa, 2019).

The physicochemical properties of indaziflam suggest a low soil sorption $\left(\mathrm{Kd}=4.9-27.4 \mathrm{~g} \mathrm{~mL}^{-1}\right)$, high persistence $\left(\mathrm{T}_{1 / 2}>200\right.$ days) and are unlikely to volatilize (vapor pressure of $5.1 \times 10^{-10} \mathrm{~mm} \mathrm{Hg}$ at $25^{\circ} \mathrm{C}$ ) (EPA, 2010; Alonso et al., 2011). Alonso et al. (2011), when evaluating the sorption of indaziflam by chromatography, affirm that there is a positive correlation between the sorption of indaziflam and the organic matter content of several Brazilian soils, classifying them with a moderate leaching potential.

Several techniques stand out in the identification and quantification of herbicides in the soil, such as mass spectrometry, radioisotopes and liquid and gas chromatography (Inoue et al., 2002; Nunes \& Vidal, 2009). As an alternative to these, the bioassays are employed, since they are simpler and less costly. To that end, the used vegetable species are of easy cultivation, high growth rate (allowing quick visualization of the occurring symptoms) and high sensitivity to the contaminant. They must also have a wide geographical distribution (so they can be used as indicators in other study sites) and genetic homogeneity (standardizing the obtained responses) (Nunes \& Vidal, 2009). These characteristics are usually found in cultivated annual species, since the breeding programs tends to select them.

In addition to its simplicity, versatility and high sensitivity, the bioassays make detecting toxic metabolites, which may not be detected by chemical methods, possible (Santos et al., 2013). They also have the ability to estimate only the biologically active fraction of the herbicide, which has direct applicability in the field conditions. However, the results presented are semi-quantitative and require calibration curves for each used herbicide, indicator species and substrate. This technique remains widely used in studies of persistence, dissipation, leaching, biological activity and dose-response of herbicides in soils (Nunes \& Vidal, 2017; Pereira et al., 2017; Silva et al.,
2017). Nonetheless, there are few studies with indaziflam in tropical soils that are conducted with biological techniques.

Several species have been used as indicators of indaziflam residues in the soil, such as the cucumber (Guerra et al., 2016a), ryegrass (Jhala et al., 2012), beet and soybean (Guerra et al., 2016b). Guerra et al. (2014) pointed out soybean, sorghum, maize, cucumber and beet as indaziflam indicators. However, sorghum, maize, beet and cucumber plants did not germinate even in the soil that received the lowest tested dosage, $20 \mathrm{~g}$ a.i. ha ${ }^{-1}$, which makes the definition of $\mathrm{C}_{50}$ inconsistent and also, consequently, the definition of the best indicator among them. On the other hand, Braga (2017) reports that sorghum is highly sensitive to indaziflam, using this species as an indicator plant in their studies. Defining the best bioindicator species and the best growth and/or development characteristic enables the detection of small residues amounts.

In view of the above-mentioned, this study aimed to select indicator species and characteristics of these plants that facilitate the detection of indaziflam residues in the soil.

\section{Materials and Methods}

The assay was conducted in a greenhouse on the campus from the Federal University of Viçosa, in a completely randomized experimental design, in a factorial scheme, with four replicates. The factors were consisted of nine vegetable species and 10 indaziflam doses.

The vegetable species Cucumis sativus (cucumber), Glycine max (soybean), Phaseolus vulgaris (common bean), Beta vulgaris (beet), Helianthus annuus (sunflower), Zea mays (maize), Sorghum bicolor (sorghum), Triticum spp. (wheat) and Avena sativa (oat) were cultivated in inert substrate containing the following indaziflam concentrations: $0 ; 0.06 ; 0.12 ; 0.25 ; 0.5 ; 1$; 2; 3; 5 e $10 \mathrm{~g} \mathrm{ha}^{-1}$, taking into account that the recommendation of the manufacturer is up to $120 \mathrm{~g}$ a.i. ha ${ }^{-1}$ (Mapa, 2019).

The plants were cultivated in a nutrient solution added to an inert substrate (washed sand). In order to obtain it, sand (from $0.05 \mathrm{~mm}$ to $2 \mathrm{~mm}$ ) was washed in running water to remove the impurities; and subsequently incubated in diluted sulfuric acid (10\%) for 24 hours. Afterwards, the material was washed under running water once more, until complete removal of the acidic residue, followed by correction of the final $\mathrm{pH}$ to neutrality, by means of controlled addition of a sodium hydroxide solution. After concluding this process, the sand was dried in the sun (Braga, 2017).

Pots made from polyethylene, with sealed bottoms and capacity for $100 \mathrm{~cm}^{3}$, were filled with $100 \mathrm{~g}$ of the inert substrate. Thereafter, the different indaziflam doses were applied in each pot, aided by a backpack sprayer equipped with a bar containing two $\mathrm{CO}_{2}$ pressurized 8002 spray nozzles, calibrated at a pressure of 3 bar, applying the equivalent to $100 \mathrm{~L} \mathrm{ha}^{-1}$ of the spray mixture. After applying the herbicide, the substrate of each pot was placed in a polyethylene bag to facilitate the herbicide homogenization. Soon after incorporating the product into the substrate, the material was put back into the pot and in the sequence, 10 seeds of each indicator species were sown per pot at a depth of $1 \mathrm{~cm}$. 
After sowing, the pots were normally irrigated daily according to the need and also at every three days, with a balanced and complete solution of macro and micronutrients, which had the following concentrations ( $\mathrm{mg} \mathrm{L}^{-1}$ ) from macronutrients: 182 of $\mathrm{N}-\mathrm{NO}_{3} ; 42$ of $\mathrm{N}-\mathrm{NH}_{4} ; 31$ of $\mathrm{P} ; 195$ of $\mathrm{K}$; 120 of $\mathrm{Ca} ; 48$ of $\mathrm{Mg} ; 64$ of $\mathrm{S}^{-\mathrm{SO}_{4}}$; and from micronutrients: 0.5 of $\mathrm{B}$; 0.02 of $\mathrm{Cu} ; 5.0$ of Fe; 0.5 of $\mathrm{Mn} ; 0.05$ of $\mathrm{Zn}$ and 0.01 of Mo, in the same way for all species.

At 21 days after the emergence (DAE) of the plants, evaluations of the percentage of intoxication were performed, with scores ranging from 0 to $100 \%$, with zero implying no symptoms and one hundred meaning the death of the plants. The plants that survived the herbicide action were harvested, washed in running water and separated in shoot and roots, then taken to an oven with forced air circulation at $72{ }^{\circ} \mathrm{C}$ until reaching constant weight, in order to determine the dry weight of the roots, shoots and total. The dry weight accumulation data were converted into percentage (proportionally relative to the control treatments, which received a $100 \%$ value).
The data were subjected to the analysis of variance and regression. The regression models were chosen with the significance of the regression coefficients taken into account, as well as their biological significance. Nonlinear regressions were determined by using the exponential model of two parameters $\left\{\mathrm{Y}=\mathrm{a}^{*}\left[1-\mathrm{e}^{(-\mathrm{bx})}\right]\right.$ and $\left.\mathrm{Y}=\mathrm{a}^{*} \mathrm{e}^{(-\mathrm{bx})}\right\}$. Where, " $\mathrm{Y}$ " is the response variable; " $a$ " is the angular coefficient; " $X$ " in the explaining variable; " $b$ " is the exponential coefficient from the insertion value of the equation in the graph produced between the explanatory and the response variables. From these equations, the $C_{50}$ was established (required dose for reducing the characteristic by $50 \%$ ) and the vegetable species that are most sensitive to indaziflam were then defined.

\section{Results and Discussion}

All species used in the assay were sensitive to indaziflam (Figure 1). The plants exhibited symptoms characterized by the inhibition of germination, growth reduction and chlorosis
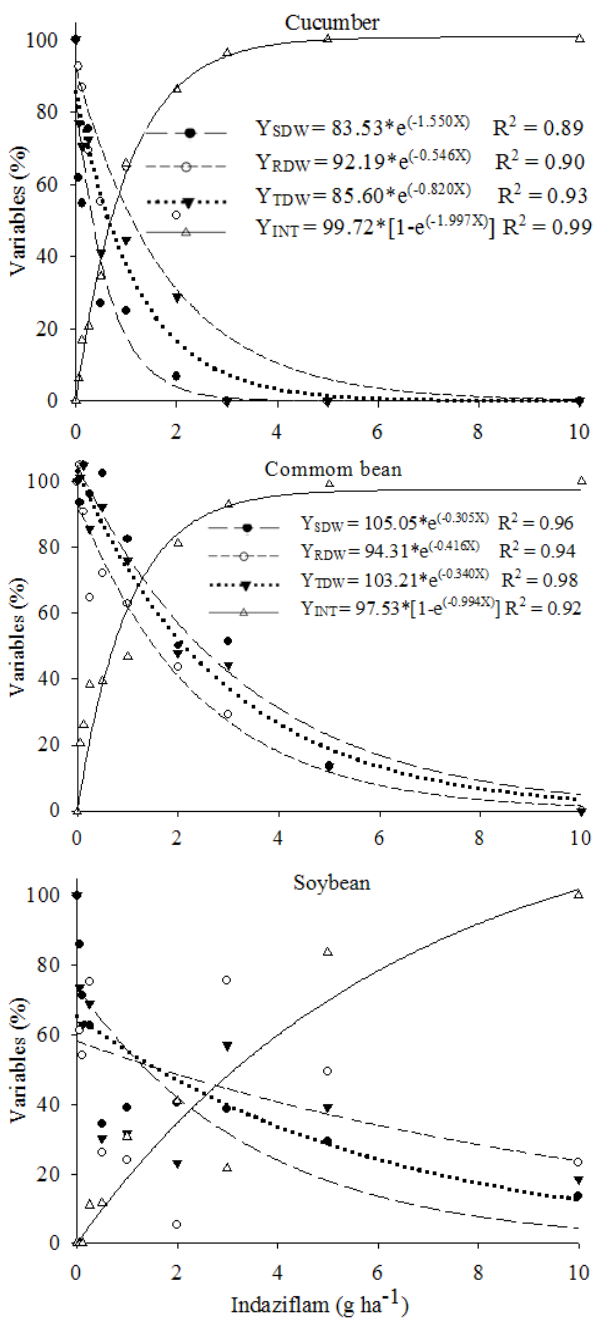

$\longrightarrow-\quad \mathrm{Y}_{\mathrm{SDW}}=73.96 * \mathrm{e}^{(-0.283 \mathrm{X})} \quad \mathrm{R}^{2}=0.66$

$--0--\quad \mathrm{Y}_{\mathrm{RDW}}=58.10 * \mathrm{e}^{(-0.089 \mathrm{X})} \quad \mathrm{R}^{2}=0.13$

$\cdots \cdots \cdots . \quad \mathrm{Y}_{\mathrm{TDW}}=65.23 * \mathrm{e}^{(-0.166 \mathrm{X})} \quad \mathrm{R}^{2}=0.39$

$\triangle \quad \mathrm{Y}_{\mathrm{INT}}=128.84^{*}\left[1-\mathrm{e}^{(-0.156 \mathrm{X})}\right] \mathrm{R}^{2}=0.90$
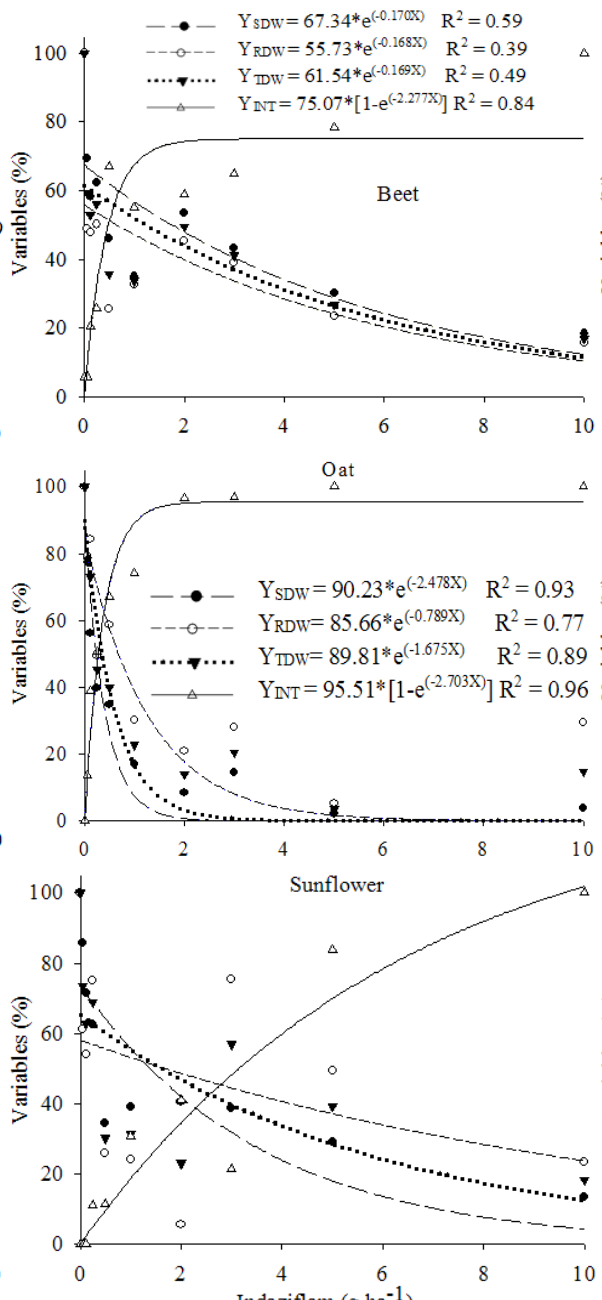

$\mathrm{Y}_{\mathrm{SDW}}=85.39 * \mathrm{e}^{(-0.235 \mathrm{X})} \quad \mathrm{R}^{2}=0.87$

--○-- $\quad \mathrm{Y}_{\mathrm{RDW}}=73.99 * \mathrm{e}^{(-0.301 \mathrm{X})} \quad \mathrm{R}^{2}=0.66$

$\cdots \cdots+\cdots . \quad \mathrm{Y}_{\mathrm{TDW}}=79.41 * \mathrm{e}^{(-0.257 \mathrm{X})} \quad \mathrm{R}^{2}=0.79$

$\triangle \quad \mathrm{Y}_{\mathrm{INT}}=100.60 *\left[1-\mathrm{e}^{(-0.47 \mathrm{X})}\right] \mathrm{R}^{2}=0.98$
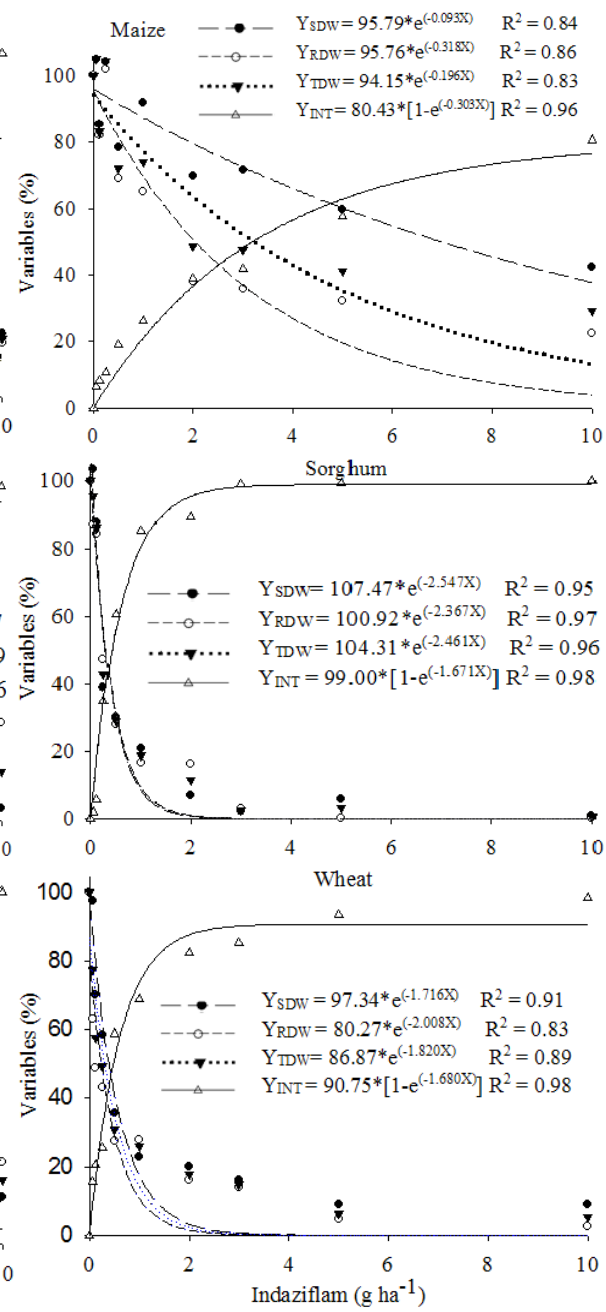

$\mathrm{SDW}=$ Shoot dry weight RDW $=$ Root dry weight TDW= Total dry weight INT $=$ Intoxication

Figure 1. Percentage, in relation to the control, of dry weight of aerial part, roots, total and intoxication of plant species cultivated for 21 days in inert substrate treated with indaziflam. 
in the leaf blade that later evolved into necrosis, with its intensity variable and depending on both the evaluated species and the applied dose (Figures 2 and 3). All evaluated vegetable species, mono or dicotyledonous, tend to suffer the indaziflam action due to its action in inhibiting cellulose biosynthesis and reducing the formation of new tissues, especially the cell wall. However, established plants are less affected because they already have developed tissues by then (Brabham et al., 2014).

Among the tested species, maize was the most tolerant to indaziflam, surviving the effects even with the application of the highest dose $\left(10 \mathrm{~g} \mathrm{ha}^{-1}\right)$. Although it caused a reduction of more than $80 \%$ in the accumulation of root dry weight (Figure 1). Guerra et al. (2014) also found less sensitivity of maize to indaziflam when compared to the other tested species. However, the sensitivity can still be considered high, since 7.0 $\mathrm{g} \mathrm{ha}^{-1}$, which corresponds to less than $10 \%$ of the commercial dose, was enough to reduce half the accumulation of shoot dry weight from this specie.

In the evaluation of plant intoxication, the most sensitive species, of lowest $C_{50}$, were oat, cucumber, sorghum, wheat, beet and the common bean, while for shoot dry weight the species were oat, cucumber, sorghum and wheat and, for root dry weight, wheat, sorghum, oat and beet (Table 1). Jeffries et al. (2014), simulating spray drift with the application of $1.8 \mathrm{~g}$ $\mathrm{ha}^{-1}$ of indaziflam, observed injuries at rates of $20 \%$ in the bell pepper and shoot dry weight reductions of $52 \%$ in soybean and $43 \%$ in bell pepper, in addition to a $20 \%$ reduction in the roots biomass of cotton, bell pepper, soybean and tomato. Nevertheless, Dias et al. (2019) reported that beet plants did not even emerge under the doses and sub-doses of indaziflam studied by these authors.

Guerra et al. (2014) reported that sorghum, soybean, sunflower and cucumber are highly sensitive to indaziflam.

The most sensitive plants considering the total dry weight were sorghum, wheat and oat (Table 1).

Sorghum, wheat and oat are always among the most sensitive plants, regardless of the tested dose or the evaluated characteristic, which indicates the use potential of these species as indicators of indaziflam residues. Monocotyledonous plants are reported to be more sensitive to indaziflam (Myers et al., 2009), which confirms the choice of sorghum, wheat and oat as indicator species of the residues from this herbicide in the soil. Amim et al. (2014) also reported that indaziflam controls grasses better than plants of broad leaves. These results corroborate those observed by Kaapro \& Hall (2012), which had greater control of grass species compared to broadleaf species by indaziflam in pine and eucalyptus plantations in Australia.

Sorghum is used in studies as an indicator of herbicide residues (Braga et al., 2016) for showing, in addition to a great sensitivity to them, an ease of being cultivated, high rate of

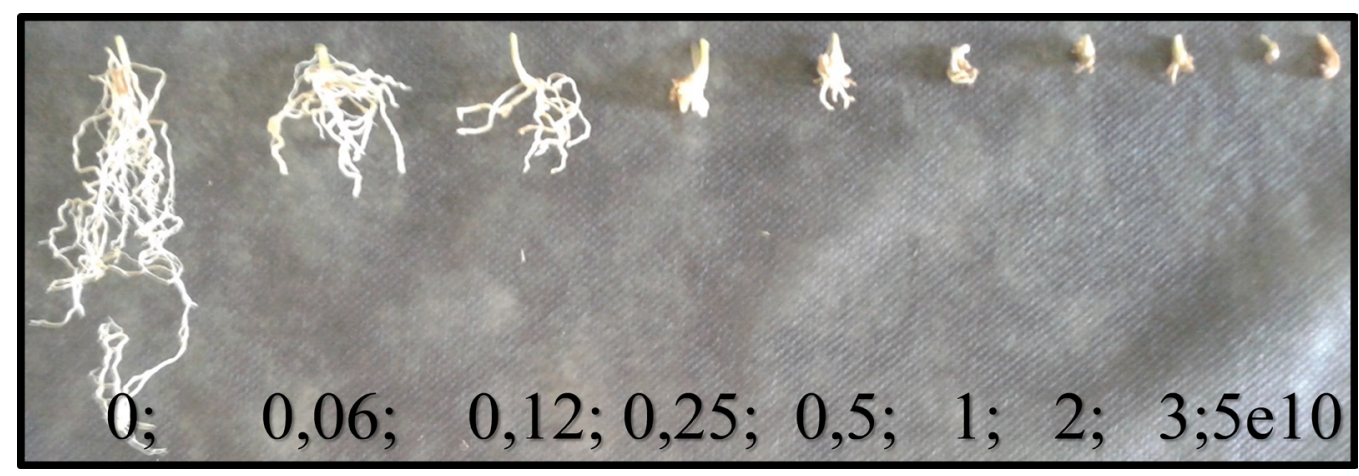

Figure 2. Indaziflam doses effect (g a.i. ha ${ }^{-1}$ ) on the growth of roots from sorghum cultivated in an inert substrate.

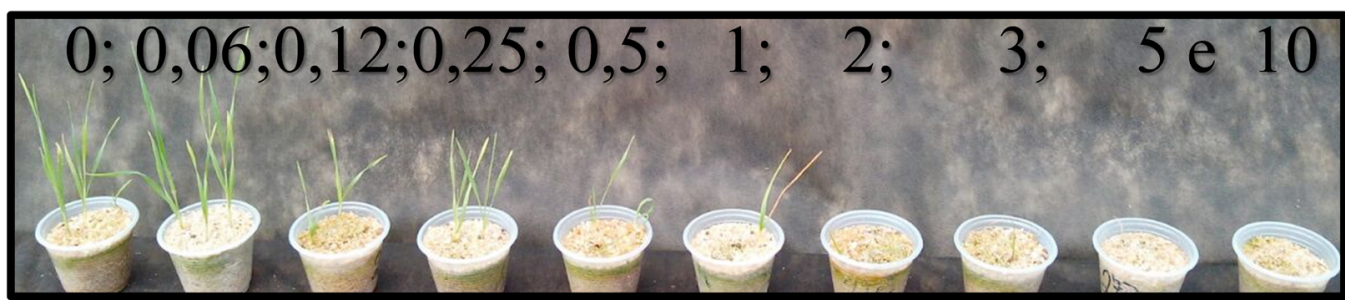

Figure 3. Indaziflam doses effect (g a.i. ha $^{-1}$ ) on the growth of roots from sorghum cultivated in an inert substrate.

Table 1. Indaziflam doses ( $\mathrm{g}$ a.i. $\mathrm{ha}^{-1}$ ) responsible for reducing intoxication and accumulation of dry weight $\left(\mathrm{C}_{50}\right)$ from the shoot, roots and the total for the different evaluated species

\begin{tabular}{ccccccccccc}
\hline $\begin{array}{c}\text { Evaluated } \\
\text { characteristic }\end{array}$ & \multicolumn{9}{c}{ Vegetable species } \\
\cline { 2 - 10 }$y$ & Cucumber & Soybean & Bean & Beet & Sunflower & Maize & Sorghum & Wheat & Oat \\
\hline Shoot dry weight & 0.33 & 1.38 & 2.42 & 1.72 & 2.27 & 6.95 & 0.30 & 0.38 & 0.24 \\
Root dry weight & 1.09 & 1.64 & 1.52 & 0.63 & 1.29 & 2.03 & 0.30 & 0.24 & 0.67 \\
Total dry weight & 0.65 & 1.60 & 2.11 & 1.21 & 1.80 & 3.20 & 0.30 & 0.30 & 0.35 \\
Plants intoxication & 0.35 & 3.16 & 0.73 & 0.48 & 1.57 & 3.20 & 0.42 & 0.47 & 0.27 \\
\hline
\end{tabular}


roots and shoot growth, resistance to pests and diseases, easy seed acquisition and tolerance to various abiotic conditions, allowing its cultivation in different environments and seasons.

Among the evaluated characteristics, the shoot dry weight is considered as the most promising one, having a greater practicality and being able to reduce errors, such as those possible in the root washing process. Jeffries et al. (2014) demonstrate that the reduction in the dry weight of shoots, roots, and plant height and injuries are at similar rates, proving an analogous behavior among the plant organs tested in this study.

\section{Conclusions}

Sorghum, oat and wheat are the most suitable species for detecting indaziflam residues.

The Sorghum bicolor species is recommended, prioritizing the evaluation of the accumulation of shoot dry weight in bioassays that seek to detect indaziflam residues.

\section{Acknowledgements}

To the Brazilian National Council for Scientific and Technological Development (CNPq), the Coordination for the Improvement of Higher Education Personnel (CAPES), the Minas Gerais Research Funding Foundation (FAPEMIG) and the Federal University of Viçosa (UFV) for the research grants, financial assistance and providing the structure to carry out the project.

\section{Literature Cited}

Alonso, D. G.; Koskinen, W. C.; Oliveira JR., R. S.; Constantin, J.; Mislankar, $\mathrm{S}$. Sorption-desorption of indaziflam in selected agricultural soils. Journal of Agricultural and Food Chemistry, v. 59, n. 24, p. 1309613101, 2011. https://doi.org/10.1021/jf203014g.

Amim, R. T.; Freitas, S. P.; Freitas, I. L. J.; Gravina, G. A.; Paes, H. M. F. Controle de plantas daninhas pelo indaziflam em solos com diferentes características físico-químicas. Planta Daninha, v. 32 , n. 4, p. 791-800, 2014. https://doi.org/10.1590/S010083582014000300017.

Brabham, C.; Lei, L.; Gu, Y., Stork, J.; Barrett, M.; Debolt, S. Indaziflam herbicidal action: a potent cellulose biosynthesis inhibitor. Plant Physiology, v. 166, n. 3, p. 1177-1185, 2014. https://doi. org/10.1104/pp.114.241950.

Braga, D. F.; Freitas, F. C. L.; Rocha, P. R. R.; Araújo, A. G. D.; Melo, V. C. Leaching of sulfentrazone in soils from the sugarcane region in the northeast region of Brazil. Planta Daninha, v. 34, n. 1, p. 161169, 2016. https://doi.org/10.1590/S0100-83582016340100017.

Braga, R. R. Sorção de indaziflam e isoxaflutole em solos tropicais. Viçosa: Universidade Federal de Viçosa, 2017. 45p. Tese de Doutorado. http://www.locus.ufv.br/handle/123456789/18697. 02 Ago. 2019.

Dias, R. C.; Gomes, D. M.; Anunciato, V. M.; Bianchi, L.; Simões, P. S.; Carbonari, C. A.; Velini, E. D. Seleção de espécies bioindicadoras para o herbicida indaziflam. Revista Brasileira de Herbicidas, v. 18, n.2, e650, 2019. https://doi.org/10.7824/rbh.v18i2.650.
United States Environmental Protection Agency - EPA. Pesticide - Fact Sheet for Indaziflam. Washington: EPA, 2010. 107p. (EPA PC Code: 080818). https://www3.epa.gov/pesticides/chem_search/reg_ actions/registration/fs_PC-080818_26-Jul-10.pdf . 15 Jul. 2019.

Griffin, J. L. Inhibition of cell wall synthesis. In: Griffin, J. L. (Ed.). Weed course. Baton Rouge: LSU, 2005. p.150-153.

Guerra, N.; Oliveira JR., R. S.; Constantin, J.; Oliveira Neto, A. M.; Gemelli, T. M. C. J.; Guerra, A. Potencial de lixiviação de herbicidas utilizados na cultura da cana-de-açúcar. Revista Ciências Exatas e da Terra e Ciências Agrárias, v. 11, n. 1, p. 42-53, 2016a. http:// revista2.grupointegrado.br/revista/index.php/campodigital/ article/view/1980/794. 02 Ago. 2019.

Guerra, N.; Oliveira Júnior, R. S.; Constantin, J.; Oliveira Neto, A. M.; Gemelli, T. M. C. J.; Guerra, A. Persistence of biological activity and leaching potential of herbicides aminocyclopyrachol and indaziflam in soils with different textures. Planta Daninha, v. 34, n. 2, p. 345355, 2016b. https://doi.org/10.1590/S0100-83582002000100016.

Guerra, N.; Oliveira Neto, A. M.; Oliveira JR., R. S.; Constantin, J.; Takano, H. K. Sensibility of plant species to herbicides aminocyclopyrachlor and indaziflam. Planta Daninha, v. 32, n. 3, p. 609-617, 2014. http://doi.org/10.1590/S0100-83582014000300017.

Inoue, M.H.; Tschope, M.C.; Mendes, K.F.; Matos, A.K.A.; Goulart, B.F.; Bem, R. Seleção de biondicadores para herbicida residuais aplicados em pré-emergência. Revista de Ciências Agro- Revista de Ciências Agro-Ambientais, Alta Floresta Ambientais, v.10, n.2, p.173-182, 2012. https://www.researchgate.net/profile/Kassio_ Mendes/publication/274696472. 10 Ago. 2019.

Jeffries, M. D.; Mahoney, D. J.; Gannon, T. W. Effect of simulated indaziflam drift rates on various plant species. Weed Technology, v. 28 , n. 4, p. 608-616, 2014. https://doi.org/10.1614/WT-D-1400004.1 .

Jhala, A. J.; Ramirez, A. H. M.; Singh, M. Leaching of indaziflam applied of two rates under different rainfall situations in Florida Clandler Soil. Bulletin of Environmental Contamination and Toxicology, v. 88, n. 3, p. 326-332, 2012. https://doi.org/10.1007/s00128-011-0514-6.

Kaapro, J.; Hall, J. Indaziflam, a new herbicide for preemergent control of weeds in turf, forestry, industrial vegetation and ornamentals. Pakistan Journal of Weed Sciences Research, v. 18, n. spe., p. 267-270, 2012. https://www.wssp.org.pk/weed/ojs/index.php/ pjwsr/article/view/438. 15 Jul. 2019.

Ministério da Agricultura, Pecuária e Abastecimento - Mapa. Agrofit 2002: sistema de informação. Brasília: Mapa, 2015. http://www. agricultura.gov.br/assuntos/insumos-agropecuarios/insumosagricolas/agrotoxicos/agrofit. 09 Ago. 2019.

Myers, D. F.; Brosnan, J. T.; Breeden, G. K.; Cooper, T.; Beck, L. L.; Straw, C. M. Indaziflam/BCS AA170717-A new herbicide for preemergent control of grasses and broadleaves in turf and ornamentals. In: Annual Meeting of the Southern Weed Science Society, 62., 2009, Orlando. Proceedings... Jackson: Southern Weed Science Society, 2009. p.393. http://www.swss.ws/wp-content/uploads/ docs/2009\%20Proceedings-SWSS.pdf. 10 Ago. 2019.

Nunes, A. L.; Vidal, R. A. Lixiviação do herbicida imazaquin associado ao paraquat ou glyphosate em plantio direto. Revista de la Facultad de Agronomía, v. 116, n. 1, p. 63-67, 2017. http:// revista.agro.unlp.edu.ar/index.php/revagro/article/view/388. 21 Fev. 2019. 
Nunes, A. L.; Vidal, R. A. Seleção de plantas quantificadoras de herbicidas residuais. Pesticidas: Revista de ecotoxicologia e meio ambiente, v. 19, n. 1, p. 19-28, 2009. https://doi.org/10.5380/ pes.v19i0.16550.

Pereira, G. A. M.; Barcellos JR., L. H.; Gonçalves, V. A.; Silva, D. V.; Silva, A. A. Clomazone leaching estimate in soil columns using the biological method. Planta Daninha, v. 35, e017163378, 2017. https://doi.org/10.1590/S010083582017350100024 .
Santos, D. P.; Braga, R. R.; Guimarães, F. A. R., Passos, A. B. R. J.; Silva, D. V.; Santos, J. B.; Nery, M. C. Determinação de espécies bioindicadoras de resíduos de herbicidas auxínicos. Revista Ceres, v. 60, n. 3, p. 354-362, 2013. https://doi.org/10.1590/ S0034-737X2013000300008.

Silva, M. M.; Santos, J. B.; Ferreira, E. A.; Brito, O.G.;Donato, L. M.S.;Santos, M. V. Forage plants and weeds that are sensitive to atmospheric clomazone residuals. Planta Daninha, v. 35, e017165078, 2017. https://doi.org/10.1590/S0100-83582017350100059. 